\title{
Micro Hydropower Plant Perspectives in Decentralized Mini Generation and Micro Markets within Brazil
}

\author{
Geraldo Lúcio Tiago Fo* \\ National Center of Small Hydro Power Plant - Brazil, Federal University of Itajubá, Brazil
}

Submission: July 15, 2018; Published: July 20, 2018

*Corresponding author: Geraldo Lúcio Tiago Fo, National Center of Small Hydro Power Plant - Brazil, Federal University of Itajubá, Av BPS, 1300, IRN, UNIFEI, Itajubá, MG, ZIP Code 37 500-903, Brazil, Tel: +55 35 36291443; Email: gltiagifilho@gmail.com

\begin{abstract}
The article presents the opinion of author on the challenges of hydroelectric micro-generation, which in the Brazilian case are less than 5 MW in the decentralized generation market in Brazil, given the regulatory and fiscal advantages given to other sources, notably solar and wind.

Keywords: Micro Generation; Deconcentrated Generation Market; Micro Hydropower plants

Abbreviations: PIS: Social Integration Program; COFINS: Social Security Financing Contribution; VAT: Value-Added Taxes; DG: Decentralized Generation; ABRAPCH: Brazilian Association of Small Hydro Power Plants and Hydroelectric Generation Plants; EIA: Environmental Impact Assessments
\end{abstract}

\section{Commentary}

Currently there is much talk of decentralized microgeneration among both the media and governmental agencies, in advertising, as well as among concessionaires. Decentralized micro-generation is basically a form of electricity generation carried out in conjunction with consumers. This is done regardless of the co-generators' power, technology, and or energy source. The co-generators are those that use Refusederived fuels as a source of energy, and emergency generators and auxiliary generators during peak times. Industry, supermarkets, and shopping malls normally use this technology while photovoltaic solar energy systems are usually used in residences and in public and residential buildings. Furthermore, small wind turbines and small hydroelectric plants called Hydroelectric Generation Plants (CGHs in Portuguese) are also used. This power generation mechanism is defined in section 14 of Decree-Law No. 5,163 / 2004, which states that "distributed generation is considered to be all electric power generation from concessionaires, licensees or authorized agents directly connected to the electric distribution system of the buyer"and regulated by Normative Resolution 482 of 2012, which was later modified by Normative Resolution 687 in 2015 by theBrazilian Electricity Regulatory Agency(ANEEL). Decentralizeddistributed generation, also known as DG, brings many environmental advantagessuch asthe use of renewable resources available in places close to the consumer, and the low environmental
impact.Because DG is geographically distributedit can mitigate environmental impacts. Transmission and distribution of electric power systems within the DG framework can result in reductions in electric power transmission and distribution costs, the reduction of transmission and distribution line losses, and can provide greater electrical voltage stability. It can also result in greater energy security, avoid systemic waste, improve transmission and distribution systemefficiency, while also reducing industry costs and investments.

Some disadvantages to DG include the low spatial concentration of available energy resources, since most DGs consist of small enterprises when compared to traditional centralized generation models.This results in higher implementation and operationalcosts, greater complexity,and systematic operational risks, not to mentionreductions in distributorrevenue.

DG in general still has to overcome several challenges if it is to consolidate its growth. The following challenges can be cited:

A. The hydroelectric sector:Energy security, reduction in distributor Revenue, and increases in grid complexity;

B. Regulation: Fees and exemption from taxes like theSocial Integration Program (PIS) tax, Social Security Financing Contribution (COFINS) tax, and State Valueadded Taxes (VAT)on services and the circulation of goods 


\section{Civil Engineering Research Journal}

(ICMS). These taxes are of equal value in all states within Brazil. Furthermore ANEEL resolutions 482 and 687 make itimpossibleto sell surplus power.

C. Technological domain:Foreign technological dependence on some sources.The lack of fully nationally produced equipment resulting in the need to import spare parts.

D. Economic Viability:The higher cost of implementation, the difficulty in financing, and the impact of distributor tariffs.

DG modalitieswithin the electric power market framework are defined asbeing either generation next to the load or by remote self-consumption that allows the surplus generated energy in one unit to be used to compensate the consumption in another unit, as long as they are in the same area.It can also be defined as consisting of multiple consumer units, which can be either in shared generation form(set forth in 2015 by ANEEL) that allows two or more consumers (natural persons or legal entities) within defined areas to join together in a consortium or cooperative to share the power generated by a system as long as allparticipants are within the same distributor concession area, or as a consumer condominium, which is formed of commercial and residential consumerswithloads above $500 \mathrm{~kW}$ intended to freely purchase energy less than $30 \mathrm{MW}$ from hydroelectric, wind, solar, and or biomass thermal power plants.

\section{The Evolution of Decentralized Generation (DG) in Brazil}

The following chart shows howdecentralized generation in Brazil has evolved since the enactment of Decree-Law No. 5,163 / 2004 (Table 1). Although the Law was enacted in 2011 and regulation was defined by ANEEL resolution 482 in 2012, DG only really started taking hold in 2013.Starting from 7 (20,4kW installed) wind farm ventures and $67(1851,14 \mathrm{~kW} n=$ installed) solar voltaic ventures, totaling $20.4 \mathrm{~kW}$ and $1852 \mathrm{KW}$ ofinstalled capacity respectively, DG has evolved to includethe current $54(10,305,6 \mathrm{~kW})$ wind farms ventures, $44(43,075.9 \mathrm{~kW})$ hydroelectric generation plants (CGHs), 86 (24.530,62kW) biomass plants, and 24.491(221.385,67kW) solar photovoltaic initiatives! The latter has been widely publicized and disseminated throughout the media as a resounding success, and it really is!

Table 1:

\begin{tabular}{|c|c|c|c|c|c|c|c|c|}
\hline & \multicolumn{4}{|c|}{ UNITS INSTALLED } & \multicolumn{4}{c|}{ CAPACITY [KW] INSTALLED } \\
\hline Month/Year & Wind & Water & Solar & Biomass & Wind & Water & Solar & Biomass \\
\hline Dec-10 & 0 & 0 & 1 & 0 & 0 & 0 & 0.5 & 0 \\
\hline Dec-11 & 0 & 0 & 12 & 0 & 0 & 0 & 44.93 & 0 \\
\hline Dec-12 & 0 & 0 & 14 & 0 & 0 & 0 & 454.73 & 0 \\
\hline Dec-13 & 7 & 0 & 67 & 0 & 20.4 & 0 & 1851.14 & 0 \\
\hline Dec-14 & 17 & 1 & 353 & 2 & 69.1 & 825 & 4252.59 & 110 \\
\hline Dec-15 & 38 & 2 & 1783 & 10 & 130.7 & 834 & 13745.77 & 2243.66 \\
\hline Dec-16 & 46 & 11 & 7906 & 39 & 5168.1 & 5455.5 & 61759.83 & 12484.48 \\
\hline Dec-17 & 53 & 39 & 21072 & 76 & 10285.6 & 39775.9 & 179466.4 & 23844.86 \\
\hline Mar-18 & 54 & 44 & 24491 & 86 & 10305.6 & 43075.9 & 221385.7 & 24530.62 \\
\hline \multicolumn{7}{|c|}{ Source: ANEEL, 03/2018 } & & \\
\hline
\end{tabular}

However, if one analyzes the same tables considering wind, biomass, and CGHs (Hydroelectric Generation Plants) generation, one can see that these sources constitute only a very smallportion relative to solar photovoltaicgeneration. In other words, the success of distributed micro-generation in Brazil can be attributed to a single energy source, that being solar photovoltaic energy!

This can be seen as either good or bad forindustry. It is good in that decentralized micro-generation has been consolidated within Brazil, and bad in that other energy sources haven't contributed to this consolidation for several reasons.

CGHs (Hydroelectric Generation Plants) present many advantages which can be cited as follows: the technological domain in Brazil, with regards toequipment production and service provision infrastructure in the whole production chain; the Social issue surrounding the capacity forjob creation, which according to studies from the Brazilian Association of Small Hydro Power Plants and Hydroelectric Generation Plants (ABRAPCH) were around 100 jobs created per MW installed; the regulatory aspect, due to the simplification of the registration process with ANEEL. Also, one may cite the large available hydraulic potential, the availability of hydrological data and, especially, the much higher service life relative to other sources. However CGHs present some disadvantages surroundingthe regulatory issue pertaining to registration with concessionariesas well as competition for other uses of hydropower that can often occur, in turn requiring greater human and financial efforts on behalf of investors.Also there are Environmental disadvantagesto be considered such as theissue of Medium Impact classification that can be submitted to more elaborate environmental impact assessments (EIAs) and may be prevented by certain local 
municipal laws The Electric system also presents disadvantages in that it has greater requirements regarding the complexity of network interconnectivity among distributors when compared to other generation sources. Finally there are economic disadvantages given the need to charge more expensive tariffs to make the venture viable, not to mention the difficulties arising from operating within aregulated market, which make smaller projects $(\mathrm{P}<500 \mathrm{~kW})$ less viable. Furthermore, it is the only source that requires proof of land ownership, leaving the entrepreneur at the mercy of landowners.

Added to all these difficulties CGHs, as with other forms of hydroelectric generation, suffer from a general lack of societal awareness, especially among environmental licensing agents who usually express aversion to this source of energy as if it were something malevolent. I would say that aversion to clean low-impact technology with genuinely national job-generating technology is quite irrational given the potential benefits of its larger scale deployment.

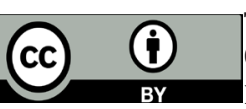

This work is licensed under Creative Commons Attribution 4.0 License DOI: 10.19080/CERJ.2018.06.555680
The challenge is then to clearly show to environmental agentsthe benefits associated with the CGH market for society as a whole. These benefits should also be presented along with the problems, however comparing them with those of other renewable energy sources.

Although the advantages of distributed generation of energy via CGHs are real, it is urgent that the CGH sectorpromote campaigns to clarify these advantages in order to increase societal awareness, overcome restrictions arising from this lack of awareness, extending also to regulatory and environmental agencies [1-3].

\section{References}

1. ANNEL (2018) Agência Nacional de Energia Elétrica.

2. (2018) INEE - Instituto Nacional de Energia Elétrica.

3. TIAGO Fo, G L, Geração Distribuída Um importante Mercado para as CGHs, lecture in $2^{\circ}$. Workshop Nacional de CGHs, ABRAPCH, 27 e 28 de Março de 2018, EXPO UNIMED - CURITIBA - PR, Portuguese.

\section{Your next submission with Juniper Publishers will reach you the below assets}

- Quality Editorial service

- Swift Peer Review

- Reprints availability

- E-prints Service

- Manuscript Podcast for convenient understanding

- Global attainment for your research

- Manuscript accessibility in different formats

( Pdf, E-pub, Full Text, Audio)

- Unceasing customer service

Track the below URL for one-step submission https://juniperpublishers.com/online-submission.php 